\title{
Safety and Efficacy of Oxandrolone in Growth Hormone-Treated Girls with Turner Syndrome: Evidence from Recent Studies and Recommendations for Use
}

\author{
T.C.J. Sas ${ }^{a, b}$ E.J. Gault ${ }^{f} \quad$ M. Zeger Bardsley ${ }^{g} \quad$ L.A. Menke ${ }^{c} \quad$ K. Freriks ${ }^{d}$ \\ R.J. Perry ${ }^{f}$ B.J. Otten ${ }^{\text {e }}$ S.M.P.F. de Muinck Keizer-Schramab H. Timmers ${ }^{d}$ \\ J.M. Wit ${ }^{\mathrm{c}}$ J.L. Ross' ${ }^{\mathrm{g}}$ M.D.C. Donaldson ${ }^{\mathrm{f}}$ \\ ${ }^{a}$ Department of Pediatrics, Albert Schweitzer Hospital, Dordrecht, ${ }^{b}$ Department of Pediatrics, Erasmus Medical \\ Centre, Rotterdam, ' Department of Pediatrics, Leiden University Medical Center, Leiden, dDivision of Endocrinology, \\ Department of Medicine, and e Department of Pediatrics, Radboud University Nijmegen Medical Centre, \\ Nijmegen, The Netherlands; ${ }^{f}$ Department of Child Health, Royal Hospital for Sick Children, University of Glasgow, \\ Glasgow, UK; ${ }^{9}$ Department of Pediatrics, Thomas Jefferson University, Philadelphia, Pa., USA
}

\section{Key Words}

Turner syndrome · Oxandrolone · Growth hormone treatment · Final height · Guidelines

\begin{abstract}
There has been no consensus regarding the efficacy and safety of oxandrolone (Ox) in addition to growth hormone $(\mathrm{GH})$ in girls with Turner syndrome (TS), the optimal age of starting this treatment, or the optimal dose. This collaborative venture between Dutch, UK and US centers is intended to give a summary of the data from three recently published randomized, placebo-controlled, double-blind studies on the effects of Ox. The published papers from these studies were reviewed within the group of authors to reach consensus about the recommendations. The addition of $\mathrm{Ox}$ to $\mathrm{GH}$ treatment leads to an increase in adult height, on average $2.3-4.6 \mathrm{~cm}$. If Ox dosages $<0.06 \mathrm{mg} / \mathrm{kg} /$ day are used, side effects are modest. The most relevant safety concerns are virilization (including clitoromegaly and voice deepening) and
\end{abstract}

a transient delay of breast development. We advise monitoring signs of virilization breast development and possibly blood lipids during Ox treatment, in addition to regular follow-up assessments for TS. In girls with TS who are severely short for age, in whom very short adult stature is anticipated, or in whom the growth rate is modest despite good compliance with $\mathrm{GH}$, adjunctive treatment with $\mathrm{Ox}$ at a dosage of $0.03-0.05 \mathrm{mg} / \mathrm{kg} /$ day starting from the age of 8-10 years onwards can be considered.

๑ 2014 S. Karger AG, Basel

\section{Introduction}

While growth hormone (GH) has been shown to improve final height (FH) in Turner syndrome (TS), such treatment can only partially overcome the growth failure observed in affected girls. It is for this reason that adjunctive therapy in TS has been tried, notably with oxandrolone $(\mathrm{Ox})$, a synthetic anabolic steroid derived from dihy-

\section{KARGER}

E-Mail karger@karger.com

www.karger.com/hrp (c) 2014 S. Karger AG, Base

$1663-2818 / 14 / 0815-0289 \$ 39.50 / 0$
T.C.J. Sas

Department of Pediatrics

Albert Schweitzer Hospital, PO Box 444

NL-3300 AK Dordrecht (The Netherlands)

E-Mail t.c.j.sas@asz.nl 
drotestosterone by replacing the carbon atom in position 2 with an oxygen atom, and methylating the carbon atom in position 17. Ox treatment, when combined with $\mathrm{GH}$, has been shown to increase height velocity in TS [1] and to improve $\mathrm{FH}[2,3]$, but its use has not become standard for two main reasons. Firstly, the patient numbers involved in previous studies reporting increased $\mathrm{FH}$ with $\mathrm{GH}$ and $\mathrm{Ox}$ have been relatively small. For example, Nilsson et al. [2] found $\mathrm{FH}$ to be greatest in girls receiving $\mathrm{GH}$ and $\mathrm{Ox}$ compared with $\mathrm{GH} \pm$ ethinyl estradiol $\left(\mathrm{EE}_{2}\right)$ and $\mathrm{GH}, \mathrm{Ox}$ and $\mathrm{EE}_{2}$, but there were 15 or fewer girls in each of the three groups, while in the study of Stahnke et al. [3] only 7 girls treated with $\mathrm{GH}$ alone and 15 girls who had received $\mathrm{GH}$ and consistent Ox treatment were at FH. Secondly, features of virilization with clitoromegaly and voice deepening have been reported with Ox doses of $0.1 \mathrm{mg} / \mathrm{kg} /$ day or more, requiring a reduction in dosage $[1,3]$. Given these concerns, and because none of the above studies were placebo $(\mathrm{Pl})$-controlled, there has to date been insufficient information about both the efficacy and safety of Ox and the optimal dose and age at starting this treatment.

The recent publication of three randomized $\mathrm{Pl}$-controlled, double-blind studies on the effects of Ox in addition to GH in girls with TS has generated more insight into the benefit-risk ratio of $\mathrm{Ox}$ [4-6].

In this paper we summarize the findings of the three recent studies [4-6] in terms of efficacy and safety, and present recommendations concerning the use of $\mathrm{Ox}$ in TS. We also draw attention to areas where our knowledge remains insufficient. Whilst a meta-analysis of the data from the three studies was carefully considered and would have the advantages of increasing sample size thus decreasing the confidence intervals, there are difficulties in applying this approach to our situation. Firstly, pooled analysis is usually more suited to situations where more than three studies are available for analysis. Secondly, there are considerable differences in Ox dosage and in timing of $\mathrm{GH}, \mathrm{Ox}$ and estrogen treatment between the treatment regimens of the three studies. Finally, metaanalysis of the results of these three studies could obscure the influence of the various treatment regimens. For these reasons we have chosen to simply compare and contrast the results from each study.

\section{Efficacy of Ox in GH-Treated Girls with TS}

Table 1 outlines the characteristics while table 2 gives the results of the three $\mathrm{Pl}$-controlled studies on the effect of $\mathrm{Ox}$ in girls with TS who were treated with $\mathrm{GH}$.
In 2010, Menke et al. [4] reported the data of a Dutch randomized, Pl-controlled, double-blind, dose-response study performed in ten centers in the Netherlands. A total of 133 patients with TS were grouped according to age as follows: group 1 (2-7.99 years), group 2 (8-11.99 years), or group 3 (12-15.99 years). Patients were treated with $\mathrm{GH}$, maintaining a dose of $1.33 \mathrm{mg} /$ $\mathrm{m}^{2} /$ day, equivalent to $46 \mu \mathrm{g} / \mathrm{kg} /$ day for a body surface of $1 \mathrm{~m}^{2}$, from baseline throughout the study. They were also randomized to receive either $\mathrm{Pl}$ or $\mathrm{Ox}$ in a low $(0.03$ $\mathrm{mg} / \mathrm{kg} /$ day $)$ or conventional $(0.06 \mathrm{mg} / \mathrm{kg} /$ day $)$ dose from the age of 8 years. Capsules of Ox were made by one pharmacist in predetermined strengths for daily use and the dose of Ox was rounded off to the nearest 0.5 $\mathrm{mg}$. The maximum daily $\mathrm{Ox}$ dose was $3.75 \mathrm{mg}$. Ox or $\mathrm{Pl}$ was continued for as long as GH was prescribed. Estrogen therapy was given from the age of 12 years; $17 \beta$-estradiol was prescribed in age groups 1 and 2 , and $\mathrm{EE}_{2}$ in age group 3 ( 5 and $0.05 \mu \mathrm{g} / \mathrm{kg} /$ day orally, increasing to 10 and $0.1 \mu \mathrm{g} / \mathrm{kg} /$ day, respectively, after 2 years). Adult height gain was calculated as attained adult height minus predicted adult height using a modification of the Lyon method $[5,6]$. Compared with $\mathrm{Pl}, \mathrm{Ox} 0.03 \mathrm{mg} /$ $\mathrm{kg} /$ day increased adult height gain in the intention-totreat analysis (mean $\pm \mathrm{SD}, 9.5 \pm 4.7$ vs. $7.2 \pm 4.0 \mathrm{~cm}, \mathrm{p}=$ $0.02)$ and per-protocol analysis $(9.8 \pm 4.9$ vs. $6.8 \pm 4.4$ $\mathrm{cm}, \mathrm{p}=0.02$ ). By contrast, adult height gain on $\mathrm{GH}$ and Ox $0.06 \mathrm{mg} / \mathrm{kg} /$ day was not significantly different from that on $\mathrm{GH}$ and $\mathrm{Pl}(8.3 \pm 4.7$ vs. $7.2 \pm 4.0 \mathrm{~cm}, \mathrm{p}=0.3)$ [4]. Concerning the difference in height gain between the group receiving $\mathrm{Ox} 0.03 \mathrm{mg} / \mathrm{kg} /$ day and the group receiving $\mathrm{Pl}$, this is not attributable to the former starting GH 0.9 year and Ox 0.7 year earlier since adjustments for age were made in the statistical analysis. The lack of incremental effect of the higher Ox dose of 0.06 $\mathrm{mg} / \mathrm{kg} /$ day on adult height can be explained partly by an acceleration in bone maturation $(\mathrm{p}=0.001)$ and also by the relatively high numbers of earlier termination of treatment owing to virilization.

In 2011, Zeger et al. [7] reported the results of a randomized Pl-controlled, double-blind prospective trial carried out in two centers in the USA, addressing the effect of $\mathrm{Ox}$ at a dosage of $0.06 \mathrm{mg} / \mathrm{kg} /$ day in addition to $\mathrm{GH}$ in girls with TS. Patients received combinations of 2.5and 1.25-mg Ox tablets in order to achieve the desired weekly dose. The dosage of Ox was reduced by $50 \%$ if there were signs of virilization and/or bone age advancement. Ox or $\mathrm{Pl}$ was added to $\mathrm{GH}$ for 4 years, and $\mathrm{EE}_{2}$ was started in all girls after 2 years of treatment with $\mathrm{GH}+\mathrm{Pl} /$ Ox: in year $350 \mathrm{ng} / \mathrm{kg} /$ day, and in year $4100 \mathrm{ng} / \mathrm{kg} /$ day. 
Table 1. Characteristics of three Pl-controlled studies on the effect of Ox in girls with TS treated with $\mathrm{GH} 1.33-1.43 \mathrm{mg} / \mathrm{m}^{2} / \mathrm{day}$

\begin{tabular}{|c|c|c|c|}
\hline & $\begin{array}{l}\text { Dutch study } \\
\text { Menke et al., } 2010 \text { [4] }\end{array}$ & $\begin{array}{l}\text { US study } \\
\text { Zeger et al., } 2011 \text { [7] }\end{array}$ & $\begin{array}{l}\text { UK study } \\
\text { Gault et al., } 2011[8]\end{array}$ \\
\hline \multicolumn{4}{|l|}{ Inclusion criteria } \\
\hline Karyotype & $\begin{array}{l}\text { Karyotype associated with TS } \\
\text { except Y-chromosomal } \\
\text { material }\end{array}$ & $\begin{array}{l}\text { Karyotype associated with } \\
\text { TS except Y-chromosomal } \\
\text { material }\end{array}$ & Karyotype associated with TS \\
\hline Age, years & $2-16$ & $10-15$ & $7-13$ \\
\hline \multicolumn{4}{|l|}{ Exclusion criteria } \\
\hline Previous treatment & No Ox, no E2, no GH & $\begin{array}{l}\text { No } \mathrm{Ox} \text {, no } \mathrm{E}_{2} \text {, no prior } \mathrm{GH} \\
\text { exceeding } 12 \text { months or in } \\
\text { the preceding } 3 \text { months }\end{array}$ & $\begin{array}{l}\text { No Ox, no } E_{2}, \text { no } G H \text { or only } \\
\text { GH range } 8.3-11.7 \mathrm{mg} / \mathrm{m}^{2} / \\
\text { week }\end{array}$ \\
\hline \multicolumn{4}{|l|}{ Study design } \\
\hline 'Discontinuation' criteria & $\begin{array}{l}\mathrm{GH}+\mathrm{Ox} / \mathrm{Pl} \text { were stopped } \\
\text { when height velocity }<1 \mathrm{~cm} \\
\text { in previous } 6 \text { months or be- } \\
\text { cause patients were satisfied } \\
\text { with their height }\end{array}$ & $\begin{array}{l}\text { Near-adult height defined } \\
\text { as height obtained when } \\
\text { bone age was } \geq 13.5 \text { years }\end{array}$ & $\begin{array}{l}\text { Treatment until adult height } \\
\text { was reached. Final height de- } \\
\text { fined as height velocity }<1 \mathrm{~cm} / \\
\text { year and bone age } \geq 15.5 \text { years }\end{array}$ \\
\hline Start estrogen therapy & $\begin{array}{l}\text { From the age of } 12 \text { years } \\
\text { onwards }\end{array}$ & $\begin{array}{l}\text { After } 2 \text { years }(12-17 \text { years }) \\
\text { of treatment with Ox }\end{array}$ & $\begin{array}{l}\text { Randomized to starting at } 12 \text { or } \\
14 \text { years }\end{array}$ \\
\hline Estrogen therapy, oral & $\begin{array}{l}17 \beta \text {-Estradiol: } 1 \text { st and } 2 \mathrm{nd} \\
\text { years } 5 \mu \mathrm{g} / \mathrm{kg} / \text { day; } 3 \text { rd year } \\
10 \mu \mathrm{g} / \mathrm{kg} / \text { day or } \\
\mathrm{EE}_{2}: 1 \mathrm{st} \text { and } 2 \mathrm{nd} \text { years } 50 \mathrm{ng} / \\
\mathrm{kg} / \text { day; } 3 \mathrm{rd} \text { year } 100 \mathrm{ng} / \mathrm{kg} / \text { day }\end{array}$ & $\begin{array}{l}\mathrm{EE}_{2}: 50 \mathrm{ng} / \mathrm{kg} / \text { day during } \\
\text { year } 3 \text { and } 100 \mathrm{ng} / \mathrm{kg} / \text { day } \\
\text { during year } 4\end{array}$ & $\begin{array}{l}\mathrm{EE}_{2} \text { : year } 1,2 \mu \mathrm{g} / \text { day; year } 2 \text {, } \\
4 \mu \mathrm{g} / \text { day; year } 3,4 \text { months each } \\
\text { of } 6,8 \text {, and } 10 \mu \mathrm{g} / \text { day }\end{array}$ \\
\hline
\end{tabular}

Height gain was assessed as change in absolute height and height SD score (SDS) from baseline using US National Center for Health Statistics and TS-specific standards. Seventy-six girls aged 10-14.9 years with TS were randomized to receive $\mathrm{Ox}(0.06 \mathrm{mg} / \mathrm{kg} /$ day, maximum 3.75 $\mathrm{mg} /$ day) or $\mathrm{Pl}$ in combination with $\mathrm{GH}$ (maintaining a dose of $0.35 \mathrm{mg} / \mathrm{kg} /$ week $=50 \mu \mathrm{g} / \mathrm{kg} /$ day throughout the study). At year 4, 21 out of 24 girls in the GH/Ox group and 20 out of 23 in the GH/Pl group had reached nearadult height (bone age $\geq 13.5$ years). For those who had reached near-adult height, the change in height from baseline between the $\mathrm{Ox}$ and $\mathrm{Pl}$ groups was nearly significant, those having received Ox having grown an average of $4 \mathrm{~cm}$ more $(25.4 \pm 6.7$ vs. $21.8 \pm 5.3 \mathrm{~cm}, \mathrm{p}=0.07)$ [7].
In 2011, Gault et al. [8] reported the data of a randomized, double-blind, Pl-controlled trial performed in 36 pediatric endocrinology departments in the UK. A total of 106 girls with TS aged 7-13 years at recruitment received GH therapy, maintaining a dose of $10 \mathrm{mg} / \mathrm{m}^{2} /$ week $\left(1.43 \mathrm{mg} / \mathrm{m}^{2} /\right.$ day, equivalent to $49 \mu \mathrm{g} / \mathrm{kg}$ /day for a body surface area of $1 \mathrm{~m}^{2}$ ) throughout the study, and were randomized to $\mathrm{Ox}(0.05 \mathrm{mg} / \mathrm{kg} /$ day with a maximum daily dose of $2.5 \mathrm{mg}$ /day) or $\mathrm{Pl}$ from 9 years of age. Ox was administered as either a full or a half $2.5-\mathrm{mg}$ tablet, or taken on alternate days to achieve the desired weekly dose. Those girls with evidence of ovarian failure at 12 years were further randomized to oral $\mathrm{EE}_{2}$ (year 1 : $2 \mu \mathrm{g}$ daily; year 2: $4 \mu \mathrm{g}$ daily; year 3: 4 months each of 6, 8 , and $10 \mu \mathrm{g}$ daily) or $\mathrm{Pl}$. Participants who received $\mathrm{Pl}$ as 
Table 2. Results of three Pl-controlled studies on the effect of Ox in girls with TS treated with GH $1.33-1.43 \mathrm{mg} / \mathrm{m}^{2} / \mathrm{day}$

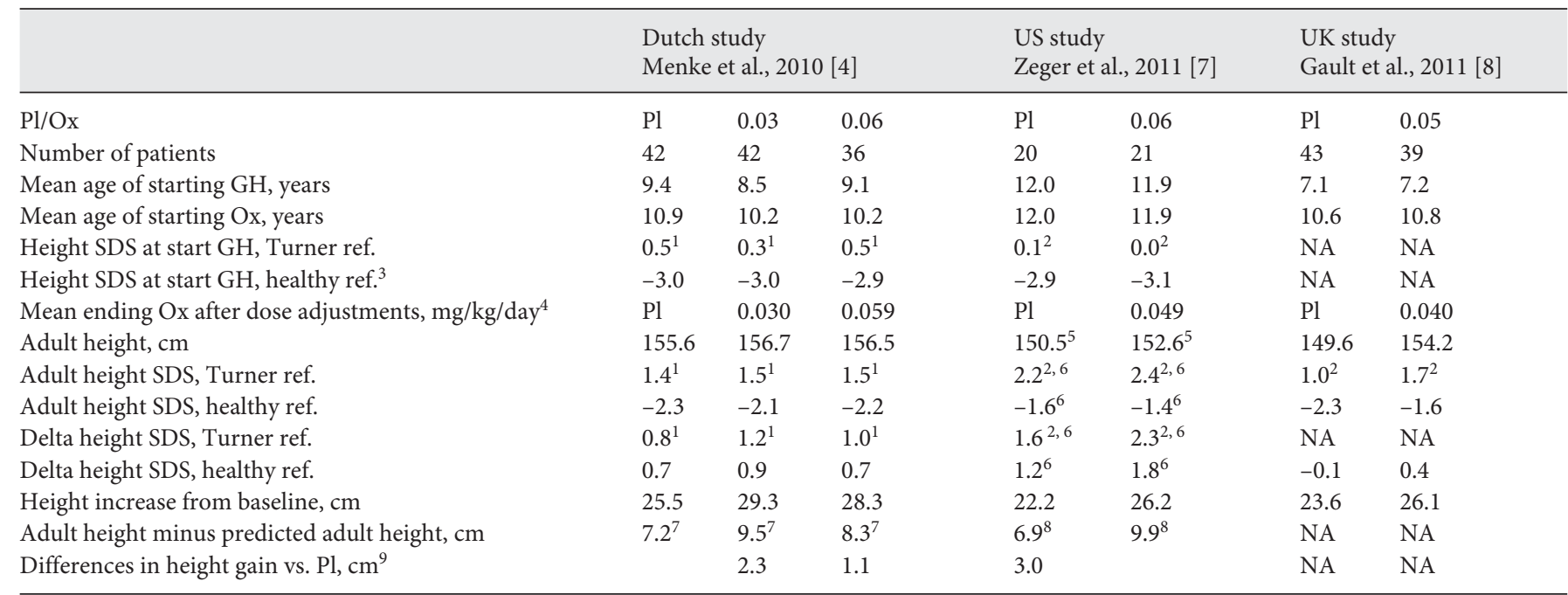

Note that height at enrolment, rather than height at start of GH, were recorded in the UK study so that data are not available for the latter.

${ }^{1}$ Turner-specific references - Dutch-Swedish-Danish data [23].

2 Turner-specific references - Lyon data [5].

${ }^{3}$ Healthy references: using reference data of healthy children of their own country.

${ }^{4}$ Ox dose adjustments: in Dutch study ceiling dose of $3.75 \mathrm{mg}$ [4]; in UK study ceiling dose of $2.50 \mathrm{mg}$ [8]; in US study ceiling dose of $3.75 \mathrm{mg}$ and dose reduction in case of virilization [7].

${ }^{5}$ Near-adult height.

${ }^{6}$ Height SDS using actual chronological age rather than 20 or 21 years of age.

${ }^{7}$ Van Teunenbroek modified projected adult height [6].

${ }^{8}$ Bayley-Pinneau method [24].

${ }^{9}$ (Near-)adult height minus predicted adult height.

well as those recruited after the age of 12.25 years started the $\mathrm{EE}_{2}$ protocol at age 14 years. Growth data were analyzed according to $\mathrm{FH}$, defined as height velocity $<1 \mathrm{~cm} /$ year and bone age at least 15.5 years, and by SITAR (SuperImposition by Translation And Rotation), a method of growth curve analysis which transforms individual growth curves, which can then be superimposed, thus defining an average summary curve for specific groups [9]. Ox increased adult height by 4.6 $\mathrm{cm}(95 \%$ confidence interval $1.9-7.2, \mathrm{p}=0.001, \mathrm{n}=82)$ and late pubertal induction (14 years) by $3.8(0.0-7.5)$ $\mathrm{cm}(\mathrm{p}=0.05, \mathrm{n}=48)$. However, mean FHs for $\mathrm{Pl} /$ late induction and $\mathrm{Ox} /$ induction at 12 years were similar $(153.1$ and $154.4 \mathrm{~cm})$ indicating that the effects of $\mathrm{Ox}$ therapy and late induction were not additive so that there was little benefit of both giving $\mathrm{Ox}$ and delaying pubertal induction [8]. The reason for this negative interaction, which nearly achieved statistical significance, is unknown.
In all three studies, Ox directly increased height velocity in girls with TS who were on standard GH treatment (1.33-1.43 mg/ $/ \mathrm{m}^{2} /$ day, equivalent to $45-50 \mu \mathrm{g} / \mathrm{kg} /$ day). Although the effect on adult height and adult height gain was calculated in different ways in the three studies, $\mathrm{Ox}$ co-treatment was associated with a greater adult height and/or adult height gain in all when compared to girls treated with GH therapy and Pl. Due to the Pl-controlled randomized design, it is unlikely that the observed differences are caused by one or more of the other factors which may influence adult height in GH-treated girls with TS, such as age at start of GH, years of GH treatment, compliance, GH dose, estrogen therapy and genetic factors.

The average effect of $\mathrm{Ox}$ on adult height gain varied between 2.3 and $4.6 \mathrm{~cm}$ in the three studies. Differences in the magnitude of the effect of Ox between the three studies may be explained by differences in the patient characteristics, dosage regimen, and limitations of the studies (table 1, 2). 


\section{Safety of Ox in GH-Treated Girls with TS}

In previous studies as well as in the three recent studies, various aspects of safety were assessed. Here we discuss virilization, delay of breast development, body proportions and composition, cardiovascular risk, bone mineral density, circulating IGF-1, and psychosocial aspects.

\section{Virilization}

The US study using Ox $0.06 \mathrm{mg} / \mathrm{kg} /$ day (with a maximum daily dose of $3.75 \mathrm{mg}$ ) showed subjective clitoral changes ( 2 girls on $\mathrm{Ox}$ and 2 on $\mathrm{Pl})$, acne ( 1 on $\mathrm{Ox}$ ) and mild hirsutism ( 3 on $\mathrm{Ox}$ ) in patients after which the $\mathrm{Ox} /$ $\mathrm{Pl}$ dose was reduced [7]. The Dutch study showed that while there were sporadic complaints about virilization in the $\mathrm{Pl}$ group (5\%), more girls in the Ox groups reported features of mild virilization (subjective voice deepening, hirsutism, and mild clitoromegaly). This was particularly evident in girls receiving $\mathrm{Ox} 0.06 \mathrm{mg} / \mathrm{kg} / \mathrm{day}$ (with a maximum of $3.75 \mathrm{mg}$ ) (42\%), and to a lesser extent in the group receiving Ox $0.03 \mathrm{mg} / \mathrm{kg} /$ day (16\%) [4]. In addition, the objective deepening of the voice was greater in the groups receiving $\mathrm{GH}+\mathrm{Ox}$ compared to those receiving $\mathrm{GH}+\mathrm{Pl}[10]$. One girl on $\mathrm{Ox} 0.03$ and 7 on $\mathrm{Ox} 0.06$ (vs. zero on $\mathrm{Pl}, \mathrm{p}=0.005$ ) discontinued $\mathrm{Ox}$ because of virilization [4]. By contrast, the UK study (using $0.05 \mathrm{mg} / \mathrm{kg} / \mathrm{day}$ with a maximum daily dose of $2.5 \mathrm{mg}$ ) did not report any virilizing effects [8].

It is at present unclear as to how the discrepancies in virilizing effects between the three studies can be explained. In the two studies using $0.06 \mathrm{mg} / \mathrm{kg} / \mathrm{day}$, virilization was noted in a substantial number of the girls $[4,7]$. In the US study, in which the study design included dose reduction, the Ox dose was reduced in about $40 \%$ of the girls because of virilization [7]. The absence of virilization in the UK study (using Ox $0.05 \mathrm{mg} / \mathrm{kg} /$ day) appears to show that this dose regimen does not lead to virilization. However, it should be noted that no systematic and specific assessment of possible virilization was carried out in this study in which investigators were simply asked to record any adverse event/reaction at each visit [8]. Another explanation may be the use of a relatively low maximal $O x$ dose in the UK study ( $2.5 \mathrm{mg} /$ day) in comparison to maximum daily dose of $3.75 \mathrm{mg}$ in the US and Dutch studies $[4,7]$. However, most girls reported virilization before they were receiving a daily dose $>2.5 \mathrm{mg}$ [unpubl. data from the Dutch study].

At present, long-term follow-up data are only available in the women who participated in the Dutch study. This follow-up study showed that even after an average period of 8.7 years, the number of girls who still subjectively experienced virilization was higher in the group that had received Ox compared to Pl [11]. There was also a trend towards a higher Ferriman-Gallwey hirsutism score with Ox (though the score was subclinical for most girls). Three girls who had received Ox still had objective clitoromegaly. In addition, the dose-dependent effect of $\mathrm{Ox}$ on lowering voice frequency, which was reported in the pediatric Dutch study [10], was also seen in the follow-up study [11]. However, only a few [7 of the 43 (16\%) Oxtreated versus 2 of the 23 (9\%) Pl-treated] patients had developed a voice frequency $<-2$ SDS; in most instances the voice frequency remained within the normal range. The percentage of patients reporting subjective voice deepening was similar between the $\mathrm{GH}+\mathrm{Ox}$ and $\mathrm{GH}+\mathrm{Pl}$ groups [11].

In conclusion, the addition of $\mathrm{Ox}(0.03-0.06 \mathrm{mg} / \mathrm{kg} /$ day) shows mild dose-dependent subjective and objective virilizing effects in girls with TS, which leads in some individuals to dose reduction or premature discontinuation of treatment. Although hirsutism and acne seem to regress after discontinuation of $\mathrm{Ox}$, clitoromegaly and voice deepening appear irreversible.

\section{Delay of Breast Development}

In all three studies, estrogens were started approximately 2 years later than the average age of onset of puberty in the non-TS population (12.5 years - and in one arm of the UK study even 14 years - compared with 10.5 years in population studies) [12]. In the Dutch follow-up study, about $50 \%$ of the women had experienced their breast development as delayed, while in $24 \%$ the delay of breast development was accompanied by negative emotions or unhappy feelings [11]. In line with expectations based on previous observations [13], Ox therapy was associated with delayed breast development in the US study as well as in the Dutch studies $[7,4]$ while this parameter was not monitored in the UK study [8]. In the US study, mean Tanner breast stage in the Ox group was approximately one stage behind that of the Pl group after 4 years. At follow-up, more patients who had received Ox had not achieved Tanner breast stage 5 than Pl-treated women [7]. In the Dutch study the increase in breast stage SDS was less with Ox 0.03 and $0.06 \mathrm{mg} / \mathrm{kg} / \mathrm{day}$ treatment than with $\mathrm{Pl}$ in the first 2 years or with discontinuation of $\mathrm{Ox} /$ Pl [4]. However, the Dutch follow-up study showed no difference in the subjective experience of delay in breast development during puberty and adolescence between the treatment groups. In addition, the effect of $\mathrm{Ox}$ on 
breast development was transient since final breast size, measured as subtraction of the smallest chest circumference (under the breasts) from the widest chest circumference (at the level of the nipples) with the patient in supine position and Tanner breast stage, was similar in the $\mathrm{Ox}$ and $\mathrm{Pl}$ groups [11].

In conclusion, girls with TS receiving Ox undergo a delay in breast development, which disappears after several years on an adult estrogen replacement dose. The consequences of this transient side effect on the patients' well-being in adolescence and adulthood are unknown.

\section{Body Proportions and Body Composition}

In the Dutch study there was a trend towards a higher sitting height using higher Ox doses compared to Pl. In addition, shoulder width was somewhat larger and hip width smaller in the Ox groups compared with the Pl group [14]. These findings were confirmed in the followup study, although the numerical difference did not reach statistical significance [11].

Regarding foot and hand length, previous reports have shown that the already relatively large foot and hand length of TS patients increase during GH treatment, with a possible additional effect in girls receiving a higher dose of GH $[15,16]$. There are no longitudinal data on the effect of Ox on hand and foot length. However, the Dutch follow-up study showed that the addition of Ox to the standard GH dose does not further increase the disproportion in foot or hand length compared with height. Head circumference was greater in both Ox-treated groups in comparison with Pl-treated girls, but the head circumference/height ratio was not different [11].

The US study found no differences in terms of change in weight SDS, body mass index SDS, and waist-to-hip ratio from baseline throughout the study between $\mathrm{Ox}$ and $\mathrm{Pl}$ [5]. In the Dutch study a reduction in fat mass and an increment in muscle mass during Ox treatment were found [14]. In the follow-up study, however, this effect of Ox on fat mass and muscle mass, measured using DEXA, was no longer observed [11]. Thus, the initial beneficial effects of Ox on body composition are transient. The UK study did not record data on body proportions or body composition [8].

In conclusion, the effects of $\mathrm{Ox}$ on body proportions (higher sitting height, broader shoulders) are mild and the effects on body composition appear to be transient.

\section{Cardiovascular Risk}

In the US study, high-density lipoprotein (HDL) cholesterol levels were lower in the Ox group from study vis- its at 6 months to 2 years, but then increased in the $\mathrm{Ox}$ group once estrogen replacement was begun so that there was less of a difference by year 4 . There was no significant difference between groups in low-density lipoprotein (LDL) cholesterol measurements for any visit. Triglycerides were lower in the Ox group than in the Pl group at years 3 and 4 [7]. The Dutch study did not present longitudinal data on lipids [4], but lipid data were obtained at the follow-up study. Eight years after discontinuation of $\mathrm{Ox} / \mathrm{Pl}$, mean HDL cholesterol was (although within the normal range) significantly lower in the Ox-treated groups than in the $\mathrm{Pl}$ group [11]. This finding suggests that the effect of Ox on lipids is not transient and may be considered as sufficient reason to monitor these during treatment.

The Dutch study showed that at start of treatment, during treatment and after discontinuation of $\mathrm{GH}+\mathrm{Pl} /$ Ox, mean systolic and diastolic blood pressure were significantly higher than in healthy girls, without significant differences between Ox dosage groups [4].

In the US and Dutch studies in which oral glucose tolerance tests were performed, the glucose and insulin levels were not significantly different between the $\mathrm{Ox}$ and $\mathrm{Pl}$ groups $[7,11,17]$.

\section{Bone Mineral Density}

Previous studies in women with TS have shown that cortical bone mineral density is lower and the fracture risk is higher than in the normal population $[18,19]$. Bone health was not reported in the Dutch or UK paper. In the US study, Ox had no effect on bone mineral density SDS [7]. Bone health data have been collected as part of the Dutch follow-up study and are being analyzed at the present time. Such long-term data will be of importance in showing whether or not $\mathrm{Ox}$ increases bone density as an androgen-related effect.

\section{IGF-1 Levels}

In the US study, IGF-1 levels were similar between the $\mathrm{Ox}$ and $\mathrm{Pl}$ groups at baseline, lower in the Ox group from 6 months to 2 years, and again similar thereafter (when estrogen was added). Serum IGFBP-3 levels were similar in the $\mathrm{Ox}$ and $\mathrm{Pl}$ groups except for the baseline and 6-month visits [7]. In the Dutch study, IGF-1 SDS values were stable over time, although levels were more frequently increased on $\mathrm{Ox}$ than on $\mathrm{Pl}$, whereas the increase in IGF-1 levels and IGF-1 to IGFBP-3 ratio (an indicator of free IGF-1) was not significantly different between the dosage groups [4]. Thus, there was no evidence for higher or lower IGF-1 levels following estro- 
gen induction in these two studies. In the UK study, IGF-1 levels were not routinely assessed as part of the protocol.

\section{Cognitive and Psychosocial Development}

In the US study a small decrease in frequency of severe arithmetic learning disability after 4 years of Ox was observed [20]. In the Dutch study, behavior problems, frequently present in untreated girls with TS, decreased during therapy, but total and internalizing problem behavior remained increased, without differences between the Ox and $\mathrm{Pl}$ groups [21]. Ox treatment was not associated with any obvious psychological symptoms which could be attributable to virilizing side effects.

\section{Recommendations}

\section{Optimal Age to Start $O x$}

The lowest age at which Ox was started in the three studies was 8 [4], 9 [8] and 10 [7] years, respectively. In view of the possible virilizing effect, starting Ox before the age of 8 years in doses between 0.03 and $0.06 \mathrm{mg} / \mathrm{kg} /$ day is not recommended. However, the effect of even lower Ox doses at $<8$ years of age has not been reported. Since many patients in the three studies were older than $8-10$ years at the start of treatment, age at the start of Ox ranged from 8 to 16 years (for details, see table 1). In the Dutch study, no statistically significant difference in the effect of Ox on adult height gain was found between the three age groups [4]. Thus, in contrast to GH treatment, starting Ox therapy as young as 8 years does not appear to be more effective than starting later. Furthermore, it might be expected that possible virilizing side effects from Ox would result in a greater psychosocial burden in a younger girl with TS than in an older girl. In conclusion, adjunctive treatment with Ox appears effective in the age range of 8-16 years. However, starting Ox relatively young, e.g. before 8 years of age, does not seem to be more favorable than starting in the early pubertal age range.

\section{Optimal Dose of Ox}

In the US [7] and Dutch $[4,11]$ studies, an Ox dose of $0.06 \mathrm{mg} / \mathrm{kg} /$ day with a relatively high maximum dose of 3.75 resulted in more virilization and increased skeletal maturation, and the efficacy was less than that of the lower dose $(0.03 \mathrm{mg} / \mathrm{kg} /$ day $)$ in the Dutch study [4]. Consequently, we believe that for most girls an Ox dose of 0.06 $\mathrm{mg} / \mathrm{kg} /$ day is too high [22]. A dose of $0.05 \mathrm{mg} / \mathrm{kg} /$ day with a maximum of $2.5 \mathrm{mg} /$ day appears to be effective and safe, as is the case with a dose of $0.03 \mathrm{mg} / \mathrm{kg} /$ day. The slightly higher adult height gain on $\mathrm{Ox} 0.05 \mathrm{mg} / \mathrm{kg} /$ day in the UK study [8] than on $0.03 \mathrm{mg} / \mathrm{kg} /$ day in the Dutch study [4] may be explained, at least partially, by the differences in baseline characteristics between the $\mathrm{Ox}$ and $\mathrm{Pl}$ groups (lower age at start in the Ox group in the UK study), and the later start of estrogens in $50 \%$ of the girls in the UK study [8]. An even lower Ox dose than $0.03 \mathrm{mg} / \mathrm{kg} / \mathrm{day}$ has not yet been studied and could theoretically still have a positive effect on height with even fewer signs of virilization. However, the currently available evidence suggests that an Ox dose between 0.03 and $0.05 \mathrm{mg} / \mathrm{kg} /$ day offers the best benefit-risk ratio. As even on a dose of 0.03 $\mathrm{mg} / \mathrm{kg}$ /day some virilization has been observed, patients and parents should be informed about these possible side effects before starting Ox. When these side effects occur, the dose should be decreased.

There is no scientific evidence to prove that a maximum daily dose for Ox should be set $(2.5 \mathrm{mg}$ in the UK study, $3.75 \mathrm{mg}$ in the US and Dutch studies) $[4,7,8]$. In most girls the complaints about virilization started before they were receiving a daily dose of $>2.5 \mathrm{mg}$ [unpubl. data from the Dutch study]. Furthermore, if a dose of $0.03 \mathrm{mg} /$ $\mathrm{kg}$ is given, most girls will never reach a dose $>2.5 \mathrm{mg}$ (given that few will surpass a body weight of $83 \mathrm{~kg}$ ). However, we suggest that if an Ox dose of $0.03-0.05 \mathrm{mg} / \mathrm{kg} /$ day is prescribed, a pragmatic ceiling dose of $2.5 \mathrm{mg}$ can be used to prevent overdosing, particularly in older and heavier girls.

\section{Conclusions on the Possible Role of Ox in TS}

The three recent controlled studies have shown that the addition of Ox to GH treatment (starting at an age between 8 and 16 years) leads to an increase in height velocity and a modest increase of adult height, on average $2.3-4.6 \mathrm{~cm}$, confirming the results of previous clinical trials. The effect of an adequate dose of GH alone on adult height is particularly dependent on the age at the start of $\mathrm{GH}$ ranging from approximately $6 \mathrm{~cm}$ in girls older than 8 years up to $10-12 \mathrm{~cm}$ in younger girls. Therefore, the additional effect of Ox can be estimated at $25-50 \%$. The cost of 5 years of Ox treatment at an average dose of 2.5 $\mathrm{mg}$ is calculated at USD 6,000-7,000, although in practice many girls will receive lower doses than this. This cost is more than outweighed by the shorter duration of $\mathrm{GH}$ treatment if $\mathrm{Ox}$ is added, estimated at approximately EUR 10,000 (USD 13,700) when Ox $0.03 \mathrm{mg} / \mathrm{kg} /$ day is used [4], 
while the efficacy in terms of adult height is approximately $3 \mathrm{~cm}$ greater. Two possible additional benefits (as yet not proven) of adjunctive treatment with Ox may be an increase of cortical thickness and a redress of the relative androgen deficiency in adolescent girls with TS. Side effects are modest if dosages are $<0.06 \mathrm{mg} / \mathrm{kg} /$ day. The most relevant safety concerns are virilization (including clitoromegaly and voice deepening), transient delay of breast development, and a decrease of HDL cholesterol, but side effects in the very long term are unknown. We advise that during Ox treatment subjective and objective signs of virilization, breast development, and blood lipids should be monitored. The laboratory costs of this are significant, estimated at USD 500 per year, but could be viewed as part of good practice in the monitoring of TS, whether or not adjunctive $\mathrm{Ox}$ is used. We believe that in girls with TS who are severely short for age, in whom very short adult stature is anticipated, or in whom the growth rate is modest despite good compliance with GH (as evidenced by normal/high IGF-1 levels), adjunctive treatment with Ox at a dosage of $0.03-0.05 \mathrm{mg} / \mathrm{kg} /$ day started from the age of 8-10 years onwards can be considered and discussed with the girl and her family.

\section{Disclosure Statement}

H. Timmers received a research grant from Pfizer for this research. T.C.J. Sas received lecture fees from Novo Nordisk and Pfizer and did advisory work for Novo Nordisk. J.M. Wit has served on the advisory boards of Pfizer, Ipsen, Versartis, Prolor, and Biopartners and received fees from Pfizer, Ipsen, and Ferring. L.A. Menke received an honorarium for her thesis from Pfizer, Eli Lilly \& Co., ACE Pharmaceuticals, Ferring, Novo Nordisk, Ipsen, and Sandoz. M.D.C. Donaldson received travel expenses from the British Society for Paediatric Endocrinology and Diabetes to attend study Steering Group meetings and royalties from endocrine textbook, consultancy fees for medicolegal reports, and lecture fees from endocrine symposia. E.J. Gault received financial support from the Scottish Executive Chief Scientist Office, the British Society for Paediatric Endocrinology and Diabetes and the Child Growth Foundation, travel expenses to attend an international meeting and a departmental honorarium for presenting preliminary results at a specialist nurse workshop, and travel expenses from the British Society for Paediatric Endocrinology and Diabetes to attend study Steering Group meetings. J.L. Ross has received grant support from Eli Lilly \& Co., Pfizer, and Novo Nordisk and has served as a consultant for Eli Lilly \& Co., Pfizer, and Novo Nordisk. M. Zeger Bardsley, R.J. Perry, K. Freriks, B.J. Otten and S.M.P.F. de Muinck Keizer-Schrama have nothing to disclose.

\section{References}

1 Rosenfeld RG, Attie KM, Frane J, Brasel JA, Burstein S, Cara JF, Chernausek S, Gotlin RW, Kuntze J, Lippe BM, Mahoney CP, Moore WV, Saenger P, Johanson AJ: Growth hormone therapy of Turner's syndrome: beneficial effect on adult height. J Pediatr 1998; 132:319-324.

2 Nilsson KO, Albertsson-Wikland K, Alm J, Aronson S, Gustafsson J, Hagenas L, Hager A, Ivarsson SA, Karlberg J, Kristrom B, Marcus C, Moell C, Ritzen M, Tuvemo T, Wattsgard C, Westgren U, Westphal O, Aman J: Improved final height in girls with Turner's syndrome treated with growth hormone and oxandrolone. J Clin Endocrinol Metab 1996; 81:635-640.

3 Stahnke N, Keller E, Landy H: Favorable final height outcome in girls with UllrichTurner syndrome treated with low-dose growth hormone together with oxandrolone despite starting treatment after 10 years of age. J Pediatr Endocrinol Metab 2002;15: 129-138.

4 Menke LA, Sas TC, de Muinck Keizer-Schrama SM, Zandwijken GR, de Ridder MA, Odink RJ, Jansen M, Delemarre-van de Waal HA, Stokvis-Brantsma WH, Waelkens JJ, Westerlaken C, Reeser HM, van Trotsenburg AS, Gevers EF, van Buuren S, Dejonckere PH, Hokken-Koelega AC, Otten BJ, Wit JM:
Efficacy and safety of oxandrolone in growth hormone-treated girls with Turner syndrome. J Clin Endocrinol Metab 2010;95: 1151-1160.

-5 Lyon AJ, Preece MA, Grant DB: Growth curve for girls with Turner syndrome. Arch Dis Child 1985;60:932-935.

-6 Van Teunenbroek A, Stijnen T, Otten B, de Muinck Keizer-Schrama S, Naeraa RW, Rongen-Westerlaken C, Drop S: A regression method including chronological and bone age for predicting final height in Turner's syndrome, with a comparison of existing methods. Acta Paediatr 1996;85:413-420.

7 Zeger MP, Shah K, Kowal K, Cutler GB Jr, Kushner H, Ross JL: Prospective study confirms oxandrolone-associated improvement in height in growth hormone-treated adolescent girls with Turner syndrome. Horm Res Paediatr 2011;75:38-46.

8 Gault EJ, Perry RJ, Cole TJ, Casey S, Paterson WF, Hindmarsh PC, Betts P, Dunger DB, Donaldson MD: Effect of oxandrolone and timing of pubertal induction on final height in Turner's syndrome: randomised, doubleblind, placebo-controlled trial. BMJ 2011; 342: 11980.

-9 Cole, TJ, Donaldson, MDC, Ben-Shlomo, Y: SITAR - a useful instrument for growth curve analysis. Int J Epidemiol 2010;39:1558-1566.
10 Menke LA, Sas TC, van Koningsbrugge SH, de Ridder MA, Zandwijken GR, Boersma B, Dejonckere PH, de Muinck Keizer-Schrama SM, Otten BJ, Wit JM: The effect of oxandrolone on voice frequency in growth hormonetreated girls with Turner syndrome. J Voice 2011;25:602-610.

11 Freriks K, Sas TC, Traas MA, Netea-Maier RT, den Heijer M, Hermus AR, Wit JM, van Alfen-van der Velden JA, Otten BJ, de Muinck Keizer-Schrama SM, Gotthardt M, Dejonckere PH, Zandwijken GR, Menke LA, Timmers HJ: Long-term effects of previous oxandrolone treatment in adult women with Turner syndrome. Eur J Endocrinol 2012;168: 91-99.

12 Mul D, Fredriks AM, van Buuren S, Oostdijk W, Verloove-Vanhorick SP, Wit JM: Pubertal development in the Netherlands 1965-1997. Pediatr Res 2001;50:479-486.

13 Labrie F: Dehydroepiandrosterone, androgens and the mammary gland. Gynecol Endocrinol 2006;22:118-130.

14 Menke LA, Sas TC, Zandwijken GR, de Ridder MA, Stijnen T, de Muinck Keizer-Schrama SM, Otten BJ, Wit JM: The effect of oxandrolone on body proportions and body composition in growth hormone-treated girls with Turner syndrome. Clin Endocrinol (Oxf) 2010;73:212-219. 
15 Sas TC, Gerver WJ, de Bruin R, Stijnen T, de Muinck Keizer-Schrama SM, Cole TJ, van Teunenbroek A, Drop SL: Body proportions during long-term growth hormone treatment in girls with Turner syndrome participating in a randomized dose-response trial. J Clin Endocrinol Metab 1999;84:4622-4628.

16 Bannink EM, van der Palen RL, Mulder PG, de Muinck Keizer-Schrama SM: Long-term follow-up of GH-treated girls with Turner syndrome: BMI, blood pressure, body proportions. Horm Res 2009;71:336-342.

17 Menke LA, Sas TC, Stijnen T, Zandwijken GR, de Muinck Keizer-Schrama SM, Otten BJ, Wit JM: Effect of oxandrolone on glucose metabolism in growth hormone-treated girls with Turner syndrome. Horm Res Paediatr 2011;75:115-122.
18 Bakalov VK, Axelrod L, Baron J, Hanton L, Nelson LM, Reynolds JC, Hill S, Troendle J, Bondy CA: Selective reduction in cortical bone mineral density in Turner syndrome independent of ovarian hormone deficiency. J Clin Endocrinol Metab 2003;88:5717-5722.

19 Gravholt CH, Vestergaard P, Hermann AP, Mosekilde L, Brixen K, Christiansen JS: Increased fracture rates in Turner's syndrome: a nationwide questionnaire survey. Clin Endocrinol 2003;59:89-96.

20 Ross JL, Mazzocco MM, Kushner H, Kowal K, Cutler GB Jr, Roeltgen D: Effects of treatment with oxandrolone for 4 years on the frequency of severe arithmetic learning disability in girls with Turner syndrome. J Pediatr 2009;155: 714-720.

-21 Menke LA, Sas TC, Visser M, Kreukels BP, Stijnen T, Zandwijken GR, de Muinck KeizerSchrama SM, Otten BJ, Wit JM, Cohen-Kettenis PT: The effect of the weak androgen oxandrolone on psychological and behavioral characteristics in growth hormone-treated girls with Turner syndrome. Horm Behav 2010;57:297-305
22 Menke LA, Sas TC, Wit JM: Comments on 'Prospective study confirms oxandrolone-associated improvement in height in growth hormone-treated adolescent girls with Turner syndrome' by Zeger et al, pp 39-47, this issue. Horm Res Paediatr 2011;75:47-48.

23 Rongen-Westerlaken C, Corel L, van den Broeck J, Massa G, Karlberg J, AlbertssonWikland K, Naeraa RW, Wit JM: Reference values for height, height velocity and weight in Turner's syndrome. Swedish Study Group for GH treatment. Acta Paediatr 1997;86: 937-942.

24 Greulich WW, Pyle SI: Radiographic Atlas of Skeletal Development of the Hand and Wrist. Stanford, Stanford University Press, 1959. 